\title{
Madrasah berbasis pesantren: Potensi menuju reformasi model pendidikan unggul
}

\author{
Deny Setiawan*, Ibrahim Bafadal, Achmad Supriyanto, Syamsul Hadi \\ Pascasarjana, Universitas Negeri Malang. \\ J1. Semarang No. 5, Sumbersari, Lowokwaru, Malang, Jawa Timur 65145, Indonesia. \\ denysetiawan3004@gmail.com \\ * Corresponding Author
}

\section{ARTICLE INFO}

\section{Article History}

Received:

30 October 2019;

Revised:

16 June 2020;

Accepted:

19 June 2020

\section{Keywords}

Madrasah;

Pendidikan unggulan;

Pesantren;

Madrasa;

Excellent education;

Islamic boarding

schools

\begin{abstract}
Artikel ini bertujuan mengakaji peluang dan tantangan pengembangan madrasah, khususnya yang berbasis pesantren. Artikel dibuat dengan meninjau dan mengumpulkan informasi dari berbagai referensi baik buku, artikel dan jurnal yang digunakan sebagai bahan dalam mempelajari dan menambah wawasan secara konseptual yang berhubungan dengan peluang dan tantangan pengembangan madrasah yang berbasis pesantren di era modern. Madrasah merupakan salah satu lembaga pendidikan alternatif dan mempunyai kesempatan yang sama untuk menjadi lembaga pendidikan yang diperhitungkan dalam dinamika perubahan sosial. Namun demikian sebagai sebuah konsekuensi logis, madrasah harus melakukan upaya-upaya agar mampu mengembangakan setiap sektor dalam rangka mewujudkan tujuan organisasinya. Upaya pengembangan madrasah di pesantren harus bisa mewujudkan kriteria pendidikan unggulan yang akan melahirkan sumber daya manusia yang memiliki kapabilitas dalam penguasaan pengetahuan dan teknologi yang dijiwai oleh nilai-nilai luhur keagamaan. Perwujudan madrasah sebagai institusi yang mampu memberikan pelayanan berupa pendidikan yang unggul, maka pesantren perlu diarahkan pemaduan antara keunggulan dalam bidang intelektual dan keterampilan dengan keunggulan dalam bidang pengetahuan keagamaan termasuk di dalamnya keunggulan dalam bidang kepribadian, keimanan dan ketaqwaan, dengan cara membuka diri dan akomodatif terhadap aspirasi dan tuntutan masyarakat serta mengaktualisasi komitmen dalam membangun pendidikan bermutu secara integral dalam seluruh proses pelaksanaan pendidikan melalui habituasi untuk mampu memahami realitas pendidikan sesuai dengan perkembangan ilmu pengetahuan dan teknologi.
\end{abstract}

This article aims to examine the opportunities and challenges of developing madrasah, especially those based on Islamic boarding schools (pesantren). Articles are made by reviewing and gathering information from various references both books, articles, and journals that are used as a material in learning and conceptually adding insight related to the opportunities and challenges of developing pesantren-based madrasah in the modern era. Madrasah is an alternative educational institution and has the same opportunity to become an educational institution that is taken into account in the dynamics of social change. However, as a logical consequence, madrasah must make efforts to be able to develop each sector in order to realize the goals of the organization. Madrasah's development efforts in Islamic boarding school must be able to realize the criteria of the superior education that will give birth to human resources who have the capability in mastering knowledge and technology that are imbued with religious noble values. The realization of madrasah as an institution that is able to provide services in the form of superior education, the Islamic boarding school needs to be directed towards the integration of intellectual and skill excellence in the field of religious knowledge including excellence in the fields of personality, faith, and devotion, by opening up and accommodating towards aspirations and demands of the community and actualizing commitments to build quality education in an integrated manner throughout the whole process of implementing education through habituation to be able to understand the reality of education in accordance with the development of science and technology.

This is an open access article under the CC-BY-SA license.

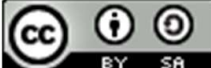

How to cite:

Setiawan, D., Bafadal, I., Supriyanto, A., \& Hadi, S. (2020). Madrasah berbasis pesantren: Potensi menuju reformasi model pendidikan unggul. Jurnal Akuntabilitas Manajemen Pendidikan, 8(1), 34-43.

doi:https://doi.org/10.21831/jamp.v8i1.27871 


\section{PENDAHULUAN}

Pada umumnya pesantren dianggap sebagai basis Islam tradisional, yakni lembaga pendidikan Islam yang terikat kuat oleh pemikiran ulama abad pertengahan yang berakar kuat pada budaya Arab Islam masa klasik (Arif, 2008, p. 188; Barizi, 2004), karena sifat ketradisionalannya, model penyelenggaraan pesantren hampir secara keseluruhan mengikuti tradisi masa lalu, baik kurikulum maupun metode pembelajarannya. Kendatipun demikian, beberapa pesantren masih tetap konsisten mempertahankan pola salafiyah yang dianggapnya sophisticated dalam menghadapi persoalan eksternal. Padahal pada kenyataannya, sebagai institusi pendidikan keagamaan dan sosial, pesantren dituntut untuk melakukan kontekstualisasi, tanpa harus mengorbankan dan menanggalkan watak dan wajah aslinya (Fadjar, Zumar, \& Dja'far, 1996).

Mengapa hal ini masih bisa terjadi? Pertama, dari segi kepemimpinan, pesantren secara kukuh masih terola dengan kepemimpian yang sentralistik dan hirarkis yang berpusat pada seorang kyai. Kedua, krisis metodologi. Di bidang metodologi, pesantren memiliki tradisi yang sangat kuat dalam bidang transmisi ilmu klasik, sehingga dalam proses pembelajarannya lebih pada menggunakan teacher-oriented daripada student-oriented (Azra, 2011). Sebab karena kurang adanya improvisasi metodologi, proses transmisi itu hanya melahirkan penumpukan kelimuan. Van Bruinesse (1995) menyatakan bahwa ilmu yang bersangkutan diangap sesuatu yang sudah bulat dan tidak dapat ditambah. Proses transmisi itu merupakan penerimaan secara taken for granted (van Bruinesse, 1995). Ketiga, terjadi disorientasi, yakni pesantren kehilangan kemampuan mendefinisikan dan memposisikan dirinya di tengah perubahan realitas sosial yang demikian cepat (MU YAPPI, 2008: 23). Sejalan dengan dinamika kehidupan masyarakat, pesantren mengalami perubahan dan perkembangan menyangkut penyeleggaraan pendidikan. Dewasa ini tidak sedikit pesantren di Indonesia telah mengadopsi sistem pendidikan formal seperti yang telah diselenggarakan oleh pemerintah. Pada umumnya, pendidikan formal yang didirikan di pesantren masih berada pada jalur pendidikan Islam, Madrasah Diniyah (MD), Madrasah Ibtidaiyah, Madrasah Tsanawiyah (MTs), dan Madrasah Aliyah (MA). Namun demikian, beberapa pesantren telah memiliki lembaga pendidikan dengan sistem Sekolah Dasar (SD), Sekolah Menengah Pertama (SMP), Sekolah Menengah Atas (SMA), Sekolah Menengah Kejuruan (SMK), bahkan sebagian membuka perguruan tinggi (Rahim, 2001).

Perubahan yang terjadi di dalam pesantren tersebut menunjukkan perkembangan ke arah penyesuaiannya dengan kebutuhan zaman. Meskipun demikian, semua perubahan itu sama sekali tidak mencabut pesantren dari akar kulturalnya. Secara umum, pesantren tetap memiliki fungsi kelembagaan yang melakukan transfer ilmu-ilmu agama (tafaqquh fi al-din), lembaga keagamaan yang melakukan kontrol sosial (social control), melakukan rekayasa sosial (social engineering) dengan tetap meneruskan sistem wetonan dan sorogan (Sulthon \& Khusnuridlo, 2006). Segala bentuk perubahan dalam pengembangan sistem pendidikan yang dilakukan pesantren bukan tanpa alasan. Pengembangan sistem tersebut didasarkan pada alasan untuk mempertahankan cara-cara lama yang masih baik (al-muhafadzah 'ala al-qadim al-salih wa al-akhdh bi al-jadid al-aslah). Kaidah ini menjadi nilai pokok dan falsafah yang melandasi kehidupan pesantren, sehingga mampu mentransformasikan potensi dan menjadikan diri pesantren sebagai agent of change bagi masyarakat (Tolkhah \& Baziri, 2004, p. 46).

Di sisi lain, tingginya ekpektasi masyarakat terhadap lulusan pesantren berdampak pada reformasi manajemen pondok pesatren dan mengharuskan memiliki lembaga formal baik yang berafiliasi ke Kementerian Agama maupun Dinas Pendidikan. Hal ini juga mengindikasikan bahwa masyarakat sudah mulai "melek" dan menyadari akan urgensi pendidikan formal pada zaman sekarang ini. Masyarakatpun mulai mengakui bahwa mempunyai kemampuan praktis tidaklah cukup untuk memberikan keyakinan bahwa kita mampu menunjukkan eksistensi di tengah persaingan yang ada. Tapi bagaimana eksistensi tersebut diikuti oleh legal formal yang akan memberikan implikasi yang berimbang antara pengakuan secara praktis dan akademis. Dengan demikian, adanya perubahan dalam sistem manajemen pesantren menggambarkan realitas dunia pesantren yang berdiri tegak di atas landasan tradisi masa lampau. Namun, dengan landasan tersebut, perubahan dapat dikelola sedemikian rupa dengan membuang elemen dan kebiasaan lama dengan memasukkan elemen baru sesuai kebutuhan masyarakat. 


\section{METODE}

Artikel ini dibuat dengan meninjau dan mengumpulkan informasi dari berbagai referensi baik buku, artikel dan jurnal yang digunakan sebagai bahan dalam mempelajari dan menambah wawasan secara konseptual yang berhubungan dengan peluang dan tantangan pengembangan madrasah yang berbasis pesantren di era modern. Setelah melakukan pengumpulan informasi dan melalui serangkaian studi literatur dan proses pemikiran, maka semua teori, konsep, fakta dan informasi mengenai peluang dan tantangan pengembangan madrasah berbasis pesantren yang diperoleh dikaji ulang kemudian diintegrasikan dalam satu lingkup bahasan yang mampu menjawab keingintahuan penulis berkaitan dengan pengembangan potensi menuju reformasi model pendidikan unggul di lingkup madrasah berbasis pesantren.

\section{HASIL DAN PEMBAHASAN}

Hasil

\section{Madrasah; Sekolah Umum Berciri Khas Agama Islam}

Penjelasan mengenai manajemen madrasah berbasis pesantren, perlu ditegaskan mengenai kedudukan madrasah dewasa ini. Meski madrasah lahir sebagi bentuk lain dari pendidikan umum berbasis pesantren yang memposisikan diri berhadap-hadapan dengan sistem pendidikan umum buatan kolonial Belanda, pada pergulatan pencarian identitasnya, belakangan madrasah memposisikan diri sebagai lembaga pendidikan umum berciri khas agama Islam. Posisi ini diambil sebagai akibat dari ketidakpuasan masyarakat terhadap sistem pendidikan pesantren yang dinilai terlalu sempit dan terbatas pada pengajaran ilmu-ilmu fard 'ain semata. Pada perkembangannya, dari masa ke masa, pengembangan madrasah semakin mengarah pada perkembangan yang lebih meluas dan komprehensif karena sudah menawarkan konsep Madrasah Aliyah Program Khusus (MAPK) yang bertujuan untuk memberikan keseimbangan pada lulusan madrasah, agar mampu menguasai ilmu-ilmu agama dan imu-ilmu umum secara komprehensif dengan mengajarkan kitab-kitab berbasa asing (khususnya Arab) serta ilmu-ilmu keislaman lainnya

\section{Tantangan Keunggulan Madrasah di Pesantren}

Mempertimbangkan proses perubahan yang terjadi di pesantren, tampak bahwa hingga dewasa ini lembaga tersebut telah memberikan kontribusi penting dalam penyelenggaraan pendidikan nasional. Keberadaan pesantren sebagai lembaga pendidikan tradisional maupun yang sudah mengalami perubahan memiliki pengaruh besar dalam kehidupan masyarakat Indonesia. Namun ironisnya, dari sekian ribu madrasah yang berada di pesantren sebagian besar kondisinya masih cukup memprihatinkan dan masih bergumul dengan berbagai persoalan, sehingga nilai tawar semakin rendah dan semakin termarginalkan. Kesan marginalitas madrasah, sebenarnya lebih banyak disebabkan karena sebagian besar madrasah lebih berorientasi pada kerakyatan (populis), pendidikan hanya dijadikan sebagai cagar budaya dan pada saat yang bersamaan ia mengabaikan kualitas dan prestasi. Dalam perkembangannya diperkirakan masih banyak madrasah yang mengalami kompleksitas masalah dan kurang berdaya menghadapi tuntutan perubahan dan tantangan yang semakin hari semakin kompleks.

Upaya melakukan reaktualisasi ini diarahkan pada perubahan madrasah dari pengelolaan seadanya menuju ke perhatian pada mutu, pengembangan dan pemberdayaan SDM yang berkualifikasi dan berkompetensi, serta melakukan sinkronisasi dengan kebijakan nasional dengan cara memenuhi standar nasional, bahkan meningkatkannya ke standar yang lebih tinggi, sehingga eksistensinya diakui di tingkat nasional, regional maupun internasional. Kemudian, untuk memainkan pearn edukatifnya dalam penyediaan sumber daya manusia yang berkualitas, pesantren harus meningkatkan mutu sekaligus model pendidikannya. Sebab, model pendidikan pesantren yang mendasarkan diri pada sistem konvensional tidak banyak membantu dalam penyediaan sumber daya manusia yang memiliki kompetensi integratif baik dalam penguasaan pengetahuan agama, penguasaan umum dan kecakapan teknologis

Madrasah Sebagai Model Pendidikan Islam yang Mencetak Ilmuwan

Volume 8, No. 1, April 2020 
Madrasah adalah contoh lembaga pendidikan yang tidak hanya berfokus pada pengetahuan yang sifatnya spiritual atau keagamaan saja namun juga pada aspek kecerdasan akademik yang menekankan prestasi anak didik dalam hal intelektual yang pada akhirnya bermuara pada berbagai ukuran akademik. Sebagai sebuah lembaga pendidikan formal berbasis pesantren, madrasah juga mengalami perubahan kurikulum karena dalam pelaksanaannya kurikulum madrasah juga mengacu pada Kurikulum yang ditetapkan oleh Dinas Pendidikan dan Kementerian Agama. Hal ini cukup memberikan sebuah refleksi bahwa madrasah juga menjadi ujung tombak dalam implementasi kurikulum Nasional dan mewujudkan lulusan yang saintis dan agamis

\section{Madrasah Berbasis Pesantren sebagai Model Pendidikan Unggul}

Sebagaimana dijelaskan pada pembahasan sebelumnya bahwa pesantren mempunyai banyak kelebihan dibandingkan dengan lembaga pendidikan lainnya karena pada dasarnya pesantren berawal dari pengahayatan dan pemahaman keagamaan kyai, kemudian diaktualisasikan sebagai amal saleh. Dinamika pesantren semakin adaptif dengan perkembangan zaman dengan menyelenggarakan madrasah berbasis pesantren, menjadikan pesantren memiliki peluang sebagai lembaga pendidikan Islam yang akan menciptakan manusia seutuhnya, dan membentuk masyarakat madani yang bercirikan masyarakat relegius, demokratis, egalitarian, toleran, berkeadilan dan berilmu. Adapun konsep model pendidikan yang digagas dalam madrasah adalah merupakan konsep pendidikan unggulan yang berangkat dari proses manajemen yang didesain sedemikian rupa dengan visi misi serta konsistensi tujuan yang jelas, sehingga memicu lingkungan yang strategid mengacu pada ukuran kualitas yang ditentukan

\section{Madrasah dan Potensi Pendidikan Unggul}

Sejalan dengan perkembangan dunia semakin maju, masyarakat dengan tingkat rasionalitas yang memadai, sudah dekat dengan tingkat rasionalitas yang memadai, sudah demikian cerdas untuk menentukan pilihan yang lebih rasional dan berwawasan ke depan, tidak lagi bersifat emosionla dan mengandalkan primordialisme. Mereka memilih lembaga pendidikan untuk anak-anaknya pun sangat rasional dan mempertimbangkan perspektif ke depan. Mereka akan menentukan pilihan kepada lembaga pendidikan yang dipandangnya ideal, yakni lembaga pendidikan yang mampu mengembangkan potensi spritual dan akhlak, mampu mengembangkan aspek intelektual, dan mampu mengembangkan potensi sosial maupun keterampilan anak didiknya.

Berangkat dari perspektif pengembangan sumber daya manusia, ada beberapa kecenderungan yang perlu diperhatikan dalam menciptakan madrasah yang unggul di pesantren, di antaranya adalah: 1.) Pendidikan semakin dituntut tampil sebagai kunci dalam pengembangan kualitas sumber daya manusia (output pendidikan), yaitu manusia yang memiliki wawasan, kemampuan, keterampilan, dan kepribadian yang sesuai dengan kebutuhan nyata yang dihadapi umat atau bangsa; 2.) Dalam perspektif dunia kerja, orientasi pada kemampuan nyata (what one can do) yang dapat ditampilkan oleh lulusan pendidikan akan semakin kuat; 3.) Sebagai dampak globalisasi, mutu suatu pendidikan suatu komunitas tidak hanya diukur berdasarkan kriteria dalam internal mereka, melainkan dibandingkan dengan pendidikan komunitas lainnya; 4.) Apresiasi dan harapan dunia pendidikan semakin meningkat, yaitu pendidikan yang lebih bermutu, relevan, dan hasilnya dapat dipertanggungjawabkan; dan 5.) Sebagai masyarakat relegius, maka pendidikan diarahkan pada penanaman karakter islami (kesalehan, kesopanan, kesabaran, keberanian, kearifan dan sebagainya) disamping memberikan kompetensi lain yang sifatnya akademik dan skill.

Keunggulan sumber daya manusia yang ingin dicapai pondok pesantren melalui madrasah yang unggul adalah terwujudnya generasi muda yang berkualitas tidak hanya pada aspek kognitif, tetapi juga aspek afektif dan psikomotorik, sehingga pengembangan madrasah dalam komunitas pesantren ke arah ini tidak hanya akan menciptakan interaksi dan integrasi keilmuan yang lebih intens dan lebih terpadu antara lain ilmu agama dan ilmu umum, tetapi juga memiliki kemampuan teoritis dan praktis tertentu yang diperlukan era global. Gagasan ini diawali dengan niat dan tekad untuk mewujudkan madrasah sebagai institusi unggulan yang mampu memadukan kekuatan ilmu pengetahuan dan teknologi (IPTEK) dan iman dan taqwa (IMTAK). Madrasah unggulan di pesantren diharapkan mampu menghasilkan sumber daya manusia ulu al albab yang digambarkan dalam kitab suci Al-Qur'an, surah Ali Imron ayat 190-191. 


\section{Strategi Mencetak Madrasah Unggulan Berbasis Pesantren}

Dalam mewujudkan madrasah menjadi istitusi unggulan tentu saja dibutuhkan strategi khusus. Strategi ini merupakan refleksi dari pemikiran bahwa dalam rangka mencapai sebuah tujuan organisasi, perlu adanya strategi agar lebih memudahkan pelaku organisasi tersebut dalam mencapai visi misi dan tujuan yang telah ditetapkan. Oleh sebab itu, ada beberapa strategi yang perlu dilakukan oleh stakeholder madrasah untuk mencapai pendidikan unggulan tersebut yaitu: 1.) Melakukan perbaikan dan pengembangan manajemen secara konprehensif dan terus menerus sehingga pesantren mempunyai visi misi dan tujuan yang jelas dalam menyelenggarakan roda pendidikan yang ada, melakukan reformasi dalam manajemen dari manajemen tradisional menuju manajemen konvensional sesuai dengan tuntutan dan kebutuhan zaman; 2.) Membangun berbagai kekuatan di madrasah, seperti membangun kompetensi, dedikasi, dan komitmen yang tinggi, memiliki siswa yang berprestasi, yakni siswa yang lahir dari proses pembelajaran yang kreatif dan efektif, mengembangkan sumber belajar yang tidak hanya berpusta pada guru, memiliki budaya madrasah yang kokoh, memiliki seorang panutan di madrasah, memiliki motivasi yang tinggi untuk mampu bersaing dan menciptakan kebersamaan yang erat dari berbagai komponen yang ada di dalam komunitas madrasah; 3.) Memperkuat kepemimpinan dan manajemen madrasah. Kepemimpinan adalah untuk mempengaruhi, mendorong, menggerakkan, mengarahkan dan memberdayakan seluruh sumber daya madrasah untuk mencapai tujuan pendidikan di madrasah. Sedangkan fungsi manajemen adalah membuat perencanaan, mengorganisasi, melaksanakan, dan mengontrol pengembangan madrasah sesuai dengan visi, misi, tujuan dan sasaran, serta berorientasi masa depan; 4.) Membangun pencitraan (image building) madrasah. Untuk membangun pencitraan, ada adagium yang harus dijadikan pegangan oleh seluruh madrasah, yaitu do a good job; do a good job; do a good job; and tell people about it; 5.) Mengembangkan program-program unggulan. Kepala madrasah harus berusaha untuk mencermati dan memetakan program-program unggulan yang sedang dan akan dikembangkan oleh kompetitornya. Pemetaan tersebut diperlukan agar tidak terjebak pada pengembangan program unggulan yang sama. Pemetaan tersebut mampu menentukan pilihan program unggulan dengan cara being different, being the first, being the best; dan 6.) Harus berani mengubah mindset atau cara berfikir umat Islam, untuk lebih peduli terhadap kepentingan sosial dan tidak terjebak ke dalam hedonism spiritual, yakni ahli ibadah yang hanya memberikan manfaat kepada dirinya saja, bukan memberi manfaat kepada orang lain.

Perlu pengembangan pendidikan di madrasah dengan menerapkan empat strategi, yaitu: 1.) Strategi substantif, yang lembaga pendidikan perlu menyajikan program-program yang komprehensif; 2.) Strategi buttom-up, yakni lembaga pendidikan harus tumbuh dan berkembang dari bawah; 3.) Strategi deregulatory, yakni lembaga pendidikan sedapat mungkin tidak terikat pada ketentuan-ketentuan baku yang terlalu sentralik dan mengikta, dalam artian diperlukan keberanian untuk melakukan pengembangan lembaga pendidikan yang out of the box; dan 4.) Strategi cooperative, yakni lembaga pendidikan perlu mengembangkan jaringan kerja sama, baik sesama lembaga pendidikan yang setingkat atau dengan yang lainnya pada tingkat regional, nasional maupun internasional.

\section{Pembahasan}

Sebagai sekolah umum yang berciri khas agama Islam, madrasah harus selalu meningkatkan kualitas SDM-nya, baik imtaq (iman dan taqwa) maupun iptek (ilmu pengetahuan dan teknologi). Pengembangan madrasah menuju sekolah umum berciri khas Islam tersebut sejatinya telah dirancang sejak Mukti Ali menawarkan konsep pengembangan madrasah melalui kebijakan SKB 3 Menteri (Menteri Agama, Menteri Pendidikan, dan menteri Dalam Negeri), yang berusaaha menyejajarkan kualitas madrasah sebanding dengan sekolah umum melalui pola kurikulum, yakni $70 \%$ terdiri dari bidang studi umum dan 30\% bidang studi agama. Dengan keluarnya SKB 3 Menteri tahun 1975 tentang peningkatan mutu pendidikan pada madrasah, masyarakat mulai mengetahui eksistensi madrasah dalam konteks sistem pendidikan nasional. Pada pasal 2 dinyatakan: 1.) Ijazah madrasah memiliki nilai yang sama dengan ijazah sekolah umum yang setingkat; 2.) Lulusan madrasah dapat melanjutkan ke sekolah umum setingkat lebih atas; dan 3.) Siswa madrasah dapat berpindah ke sekolah umum yang setingkat (Dawam \& Ta'arifin, 2008, p. 56). Persoalannya, SKB tersebut 
ditanggapi sebagian besar masyarakat muslim Indonesia sebagai upaya meminggirkan pendidikan Islam, khususnya madrasah. Ini berarti mereka hanya memahaminya dari sudut formal saja. Padahal, jika substansi SKB tersebut dipahami secara benar maka kebijakan tersebut akan berpengaruh besar dalam rangka memajukan kualitas dunia pendidikan madrasah.

Dari waktu ke waktu, pesantren semakin tumbuh dan berkembang kuantitas maupun kualitasnya. Tidak sedikit masyarakat yang menaruh perhatian dan harapan terhadap pesantren terhadap pesantren sebagai pendidikan alternatif. Terlebih lagi dengan berbagai inovasi sistem pendidikan yang dikembangkan di pesantren dengan mengadopsi corak pendidikan umum, menjadikan pesantren semakin kompetetitif untuk menawarkan pendidikan kepada masyarakat. Meski telah melakukan berbagai inovasi pendidikan, sampai saat ini pendidikan pesantren tidak kehilangan karakteristiknya yang unik yang membedakan dirinya dengan model pendidikan umum yang diformulasikan dalam bentuk sekolahan (Hanim, 2018). Memang semakin banyak pesantren yang mendirikan madrasah. Saat ini pesantren yang memiliki Madrasah Ibtidaiyah sebanyak 2072 pesantren, Madrasah Tsanawiyah ada 2721 pesantren, Madrasah Aliyah ada 1580 pesantren dan Madrasah Aliyah Keagamaan ada 176 pesantren (Qomar, 2008, p. 94).

Namun kompleksitas masalah dan tantangan hadir, setidaknya ada dua, yaitu: pertama, tantangan yang hadir dari luar dan biasa disebut sebagai tantangan global. Dalam konteks ini, madrasah harus merebut peran dan bisa mengikuti perkembangan tuntutan zaman. Kedua, masalah dan tantangan otonomi pendidikan. Hal ini menuntut sumber daya manusia yang berkualitas dan sumber pendanaan yang kuat dan besar. Tantangan-tantangan tersebut tentu saja perlu segera direspons secara positif, manakala tidak segera direspons, lambat laun madrasah di pesantren pasti ditinggal (Muhsin \& Abdul, 2009, pp. 55-56). Untuk mengatasi problematika tersebut, madrasah di pesantren harus berusaha melakukan reaktualisasi guna meningkatkan kuantitas dan kualitas lulusan, mencapai dan/atau secara bertahap mampu melampaui delapan standar nasional pendidikan sebagaimana dalam Peraturan Pemerintah Nomor 19 Tahun 2005, dan mengembangkan programprogram unggulan yang adapat meningkatkan citra madrasah di kalangan masyarakat atau pemerintah.

Oleh karenanya, sudah sewajarnya apabila perkembangan pendidikan madrasah di pesantren akan memperkuat karakter sosial sistem pendidikan nasioanl yang turut membantu melahirkan sumber daya manusia yang memiliki kehandalan penguasaan pengetahuan dan kecakapan teknologi yang senantiasaa dijiwai oleh nilai-nilai luhur keagamaan. Pesantren telah menjadi center of excellence bagi pengembangan SDM yang memiliki basis moralitas dalam kehidupan sosial. Pada akhirnya, SDM yang dilahirkan dari madrasah di pesantren ini secara ideal dan praktis dapat berperan aktif dalam setiap perubahan sosial menuju terwujudnya tatanan kehidupan sosial yang paripurna. Inilah keunggulan yang dimiliki oleh pendidikan pesantren. Madrasah merupakan suatu sistem organisasi pendidikan formal berbasis Agama Islam, yaitu lembaga sosial yang direncanakan untuk mencapai tujuan pendidikan. Madrasah merupakan sebuah sistem sosial yang unik dengan berbagai budaya individu yang berbeda menyatu ke dalam satu sistem madrasah. Oleh sebab itu, madrasah tidak akan lepas dari kepercayaan dan nilai-nilai dari masyarakat sekitarnya. Madrasah sebagai sistem sosial selalu mempertahankan batas-batas yang memisahkan dan membedakannya dari lingkungannya (Nurochim, 2016).

Supiana (2008) menambahkan bahwa konsep madrasah unggulan berangkat dari proses manajemen yang mendesain sedemikian ruap konsistensi visi dan misi dan konsistensi tujuan dengan target yang diimplementasikan dalam program kerja dengan mengakomodir keinginan lingkungan strategis mengacu pada ukuran kualitas yang ditentukan. Konsep ini tidak dapat dipisahkan dari konsep keunggulan, yaitu memberikan perspektif untuk analisis model madrasah efektif yang unggul. Keunggulan ini dapat diukur dari pencapaian target sebagai bagian dari pencapaian visi dan misi pendidikan madrasah yang jelas dan konsisten dengan orientasi peningkatan mutu. Tegasnya, pendekatan unggulan dilakukan melalui manajemen yang dirancang mengarah pada peningkatan mutu secara berkelanjutan (Supiana, 2008).

Dengan demikian konsep pendidikan unggul pada madrasah dapat dinterpretasikan sebagai wujud dari madrasah yang bermutu. Membicarakan tentang mutu dapat berbeda makna bagi setiap orang, karena mutu memiliki banyak kriteria dan sangat tergantung pada konteksnya. Mutu merupakan konsep yang terus mengalami mengalami perkembangan dalam pemaknaannya. Nasution 
(2010) mengartikan mutu dengan kepuasan pelanggan sepenuhnya (full custumer satisfaction). Dalam pengertian ini, madrasah bermutu adalah madrasah berbasis agama Islam yang dapat memuaskan pelanggannya, baik pelanggan internal maupun eksternal (Nasution, 2010, p. 3). Pendidikan yang memfokuskan diri pada mutu akan terus berupaya mengembangkan program dan layanan yang memenuhi kebutuhan pengguna seperti sifat dan masyarakat. Masyarakat yang dimaksud adalah secara luas sebagai pengguna lulusan, yaitu dunia usaha, lembaga pendidikan, pemerintah dan masyarakat luas, termasuk menciptakan usaha sendiri oleh lulusan. Sehingga lembaga pendidikan dikatakan bermutu, jika dapat memenuhi persyaratan yang dituntut oleh pengguna jasa pendidikan. Bila performanya dapat melebihi persyaratan yang dituntut oleh stakeholders (user), maka suatu lembaga pendidikan baru bisa dikatakan unggul. Mutu sangat ditentukan oleh spesifikasi standar yang ditetapkan dan selalu disesuaikan dengan kebutuhan pelanggan (Widodo, 2011, pp. 19-20).

Pendidikan bermutu dapat dilihat dari sisi prestasi siswa, proses pembelajaran, kemampuan lulusan dalam mengembangkan potensinya di masyarakat serta dalam hal memecahkan masalah dan berfikir kritis. Oleh karena itu, perlu mengkaji mutu dari segi proses, produk maupun sisi internal dan kesesuaian. Mutu dilihat dari proses adalah keefektifan dan efisiensi seluruh faktor berperan dalam proses pendidikan, misalnya kualitas guru, sarana-prasarana sekolah, suasana belajar, kurikulum yang dilaksanakan, dan pengelolaan madrasah. Lulusan dari madrasah yang mempunyai faktor-faktor yang mendukung proses pembelajaran bermutu tinggi, maka akan mempunyai pengetahuan, keterampilan, dan kemampuan yang tinggi pula (Kamaruddin, 2009, p. 83). Secara efisiensi internal, pendidikan yang unggul dan bermutu adalah pendidikan yang tujuan institusi dan kurikulernya dapattercapai, sedangkan dilihat dari kesesuaian, pendidikan yang bermutu adalah pendidikan yang kemampuan lulusannya sesuai dengan kebutuhan tenaga kerja dan sesuai dengan kriteria pada penerimaan siswa baru (Sopiatin, 2010, pp. 5-6). Dikaitkan dengan tujuan nasional, maka pendidikan yang bermutu berdasarkan Undang-Undang Nomor 20 Tahun 2003 tentang Sistem Pendidikan Nasional Pasal 3 adalah pendidikan yang bermutu adalah pendidikan yang mampu mewujudkan berkembangnya potensi peserta didik agar menjadi manusia beriman dan bertaqwa kepada Tuhan Yang Maha Esa, berakhlak mulia, sehat, berilmu, cakap, kreatif, mandiri, demokratis, serta bertanggung jawab. Terkait dengan karakteristik madrasah unggulan, Muhaimin (2011) mengemukakan bahwa:

1.) Dari aspek output, dilihat dari prestasi akademik yang ditunjukkan dengan Nilai Ujian Akhir, lomba karya imiyah, lomba mata pelajaran, serta prestasi non-akademik ditunjukkan dengan keingintahuan yang tinggi, kerja sama yang baik, toleransi, kedisiplinan, kerajinan, prestasi olah raga dan seni; 2.) Dari aspek proses, diukur dari pembelajaran efektif, kepemimpinan kepala madrasah yang kuat, lingkungan yang aman dan tertib, pengelolaan tenaga kependidikan yang efektif, memiliki budaya mutu, memiliki team work kompak, cerdas, dan dinamis, memiliki kemandirian, adanya partisipasi yang tinggi dari masyarakat, mempunyai keterbukaan, mempunyai kemauan untuk berubah baik psikologis maupun fisik, melakukan evaluasi dan perbaikan secara berkelanjutan, responsif dan antisipatif terhadap kebutuhan, mempunyai komunikasi yang baik, mempunyai akuntabilitas, memiliki dan menjaga sustainabilitas dalam program pendanaan; dan 3.) Dari segi input, diukur dari memiliki kebijakan, tujuan, dan sasaran mutu yang jelas, adanya sumber daya yang tersedia dan siap, staf yang kompeten, dan berdedikasi tinggi, memiliki harapan prestasi tinggi, fokus pada pelanggaan ditandai dengan tugas yang jelas, rencana rinci dan sistematis, program yang mendukung pelaksanaan rencana dan sistem pengendalian mutu yang efektif (Muhaimin, 2011, pp. 104-105)

Mencermati beberapa kriteria tersebut di atas, terlihat bahwa pendidikan madrasah yang unggul harus mencakup siswa, sarana dan prasana, lingkungan madrasah, tenaga pendidik, kurikulum, proses belajar, program-program muatan lokal dan pengembangan diri bahkan berkaitan dengan pembinaan yang panjang, artinya madrasah harus mampu mengembangkan anak sepenuhnya sehingga dibutuhkan asrama. Namun demikian, perlu dibuktikan dengan besarnya animo masyarakat yang ingin menyekolahkan anaknya di madrasah tersebut. Kondisi ini juga menandakan bagaimanapun sebuah madrasah jika tidak dimintai oleh masyarakat, madrasah tersebut tidak 
memiliki nilai keunggulan. Sehubungan dengan konteks pendidikan Islam di Indonesia, ada beberapa kriteria tambahan dari madrasah unggulan, yaitu memiliki keagungan akhlak dan keluhuran budi, terciptanya budaya relegius di madrasah, integrasi antara wawasan agama dan umum dalam proses pembelajaran, pengembangan kognitif, kepribadian dan spritual siswa secara integratif dan menyeluruh (Maimun \& Fitri, 2010, p. 46).

Dewasa ini, selera dan kecenderungan masyarakat terhadap pendidikan mengalami perubahan. Sebelumnya, madrasah hanya dituntut untuk mengahasilkan lulusan yang lebih menguasai ilmu agama. Saat ini, masyarakat menginginkan madrasah mampu menghasilkan lulusan yang mempunyai kompetensi yang komprehensif, mampu menguasai pendidikan agama (iman dan taqwa) maupun ilmu umum (ilmu pengetahuan dan teknologi). Bahwa banyak orang tua siswa yang menginginkan dokter yang ulama dan ulama yang doketer, teknorat yang ulama atau ulama yang teknorat, peneliti yang ulama atau ulama yang peneliti, dan profesi lain yang memiliki penguasaan agama yang sangat baik (Muhaimin, 2011).

Dalam konteks ini, madrasah memiliki peluang untuk memenuhi tuntutan masyarakat tersebut, dengan beberapa alasan, yaitu: 1.) Terjadinya mobilitas sosial, yakni munculnya masyarakat menengah baru terutama kaum intelektual yang akhir-akhir ini mengalami perkembangan pesat (Imam Suprayogo, 2007, p. 55), kelas menengah baru memiliki peran besar dalam proses transformasi sosial yang berimplikasi pada tuntutan terhadap fasilitas pendidikan sesuai dengan aspirasinya baik cita-cita maupun status sosialnya; 2.) Munculnya kesadaran baru dalam beragama (santrinisasi), terutama pada masyarakat perkotaan, kelompok masyarakat menengah atas, sebagai akibat dari proses re-islamisasi yang dilakukan secara intens oleh organisasi-organisasi keagamaan, lembaga-lembaga dakwah atau yang dilakukan secara perorangan (Djamas, 2009, p. 198); dan 3.) Arus globalisasi dan moderenisasi yang demikian cepat perlu disikapi secara arif. Moderenisasi dengan berbadai dampaknya perlu disiapkan manusia-manusia yang memiliki dua kompetensi sekaligus, yakni ilmu pengetahuan dan teknologi (IPTEK) dan nilai-nilai spritualitas keagamaan. Arus globalisasi dan moderenisasi berimplikasi pada tuntutan dan harapan masyarakat terhadap pendidikan yang di samping dapat mengembangkan potensi akademik ilmu pengetahuan dan teknologi juga internalisasi nilai-nilai religiusitas (Maimun \& Fitri, 2011, p. 2).

Kondisi tersebut menuntut perubahan madrasah di pesantren, bahkan dalam beberapa tahun terakhir. Muncul dan berkembang minta kalangan masyarakat muslim Indonesia untuk membangun madrasah unggulan dalam berbagai jenjang pendidikan. Tujuannya sudah jelas, yakni mencapai keunggulan (excellence) tidak hanya dalam bidang keagamaan, tetapi juga dalam bidang ilmu umum (Azra, 2011). Oleh karena itu, madrasah di pesantren selain menyiapkan siswanya pandai agama dan memiliki perilaku yang agamis, namun juga harus menyiapkan berbagai sumber daya yang membuat siswanya pandai dalam berbagai ilmu pengetahuan, teknologi, olahraga dan seni. Perubahan ini tentu sja tidak cukup kalau hanya mengubah kurikulum, tetapi juga terpenting adalah mengubah cara berfikir seluruh komponen tentang paradigma baru madrasah. Perubahan cara ini kemudian akan mempengaruhi perubahan tentang berbagai nilai-nilai di madrasah tersebut yang pada akhirnya juga akan mempengaruhi terhadap perubahan budaya madrasah (Muhaimin, 2011).

Dilihat dari tuntutan internal dan tantangan eksternal global, maka keunggulan yang harus dimiliki madrasah di kalangan pesantren adalah penguasaan atas sains dan teknologi dan keunggulan kualitas sumber daya manusia. sesuai dengan tujuan pembangunan Indonesia untuk mewujudkan manusia yang sejahtera lahir batin, maka penguasaan atas sains dan teknologi memerlukan perspektif etis dan panduan moral, sehingga pada gilirannya akan berimbas pada peningkatan daya saing serta posisi tawar yang tinggi di bidang-bidang lain dalam globalisasi ini (Zulkarnain, 2008, p. 104).

\section{SIMPULAN}

Untuk mengembangkan sistem pendidikannya menjadi institusi yang unggul serta dalam rangka mempertahankan eksistensinya, madrasah di pesantren dituntut untuk membuka diri dan akomodatif terhadap aspirasi dan tuntutan masyarakat. Madrasah perlu mengembangkan diri sehingga menjadi madrasah yang bermutu dan unggul, serta menjadin jembatan penghubung dengan sistem pendidikan nasional, terutama tentang pembinaan moral dan kepribadian siswa. Hal ini dapat dipahami karena masyarakat berharap agar produk lembaga pendidikan di pesantren adalah ahli ilmu 
agama, bermoral, dan memiliki skill untuk masa depannya. Faktor lain yang tidak kalah pentingnya dalam mewujudkan madrasah unggulan di pesantren adalah nilai-nilai kepesantrenan yang diaktualisasikan secara integral dalam seluruh proses pelaksanaan pendidikan. Nilai-nilai itu diterjemahkan dalam perilaku pengelolaan madrasah dan membangunkan komitmen mereka untuk mewujudkan pendidikan yang bermutu. Oleh karena itu, habituasi pesantren sangat signifikan dalam menanam kesadaran, baik potensi atau kultural. Melalui habituasi inilah, para siswa diajak untuk mampu memahami realitas pendidikan sesuai dengan perkembangan ilmu pengetahuan dan teknologi. Mengingat pesantren sesungguhnya merupakan sebuah lembaga pendidikan yang ideal karena menyediakan laboratorium kecakapan hidup (life skill) yang sangat bermanfaat bagi keilmuan dan aktualisasi diri santri.

\section{DAFTAR PUSTAKA}

Arif, M. (2008). Pendidikan Islam transformatif. Yogyakarta: LkiS.

Azra, A. (2011). Paradigma baru pendidikan nasional, rekonstruksi dan demokratisasi. Jakarta: Penerbit Buku Kompas.

Barizi, A. (2011). Pendidikan integratif, akar tradisi dan keilmuan pendidikan Islam. Malang: UIN Malang Press.

Dawam, A., \& Ta'arif, A. (2008). Manajemen madrasah berbasis pesantren. Jakarta: PT. Listafarika Putra.

Djamas, N. (2009). Dinamika pendidikan Islam di Indonesia pasca kemerdekaan. Jakarta: Raja Grafindo Persada.

Fadjar, A. M., Zumar, D., \& Dja'far, S. F. (1999). Reorientasi pendidikan Islam. Fajar Dunia.

Hanim, Z. (2018). Educational Management of Educational Institutions In Limitation's State. International Journal of Scientific Research and Management, 6(6). doi:https://doi.org/10.18535/ijssm/v6i6.el02

Kamaruddin, U. (2009). Landasan ilmu pendidikan. Jakarta: Rajawali Pers.

Maimun, A., \& Fitri, A. Z. (2010). Madrasah unggulan, lembaga alternatif di era kompetitif. UIN Malang: Maliki Press.

MU YAPPI. (2008). Manajemen pengembangan pendidikan pesantren. Jakarta: Media Nusantara.

Muhaimin, M. (2011). Pemikiran dan aktualisasi pengembangan pendidikan Islam. Jakarta: Raja Grafindo Persada.

Muhsin, B., \& Abdul, W. (2009). Pendidikan Islam kontemporer. Bandung: Refika Aditama.

Nasution, N. (2010). Manajemen mutu terpadu (total quality management). Bogor: Ghalis Indonesia.

Nurochim, N. (2016). Sekolah berbasis pesantren sebagai salah satu model pendidikan Islam dalam konsepsi perubahan sosial. Universitas Islam Negeri Syarif Hidayatullah.

Presiden Republik Indonesia. (2003). Undang-Undang Nomor 20 Pasal 3, Tahun 2003, tentang Sistem Pendidikan Nasional.

Qomar, M. (2018). Pesantren dan transformasi metodologi menuju demokratisasi institusi. Jakarta: Erlangga.

Rahim, H. (2001). Arah baru pendidikan Islam di Indonesia. Jakarta: Logos.

Sopiatin, P. (2010). Manajemen belajar berbasis kepuasan siswa. Bogor: Ghalia Indonesia.

Sulthon, M., \& Khusnuridlo, M. (2006). Manajemen pondok pesantren dalam persepktif global. Yogyakarta: Laksbang. 
Supiana, S. (2008). Sistem pendidikan madrasah unggulan di MAN Insan Cendikia Tangerang, MAN 1 Bandung, dan MAN Darussalam Ciamis. Jakarta: Badan Litbang dan Diklat Departemen Agama RI.

Tolkhah, I. \& Baziri, A. (2004). Membuka jendela pendidikan: Mengurai akar tradisi dan integrasi keilmuan pendidikan. Yogjakarta: PT Raja Grafindo Persada.

Van Bruinessen, M. (1995). Kitab kuning, pesatren dan tarikat, Bandung: Mizan.

Widodo, S. E. (2011). Manajemen mutu pendidikan untuk guru dan kepala sekolah. Jakarta: Ardadizya Jaya.

Zulkarnain, Z. (2008). Transformasi nilai-nilai pendidikan Islam, manajemen berorientasi link and match. Yogyakarta: Pustaka Pelajar. 